\title{
The distribution of trace elements in sulfides and magnetite from the Jaguar hydrothermal nickel deposit: A potential link between IOA and IOCG deposits within the Carajás Mineral Province?
}

\author{
EDUARDO MANSUR ${ }^{1}$, SARAH A. S. DARE ${ }^{1}$ AND CESAR \\ FERREIRA FILHO ${ }^{2}$ \\ ${ }^{1}$ Universite du Quebec a Chicoutimi (UQAC) \\ ${ }^{2}$ Universidade de Brasilia (UnB) \\ Presenting Author: etmansur@gmail.com
}

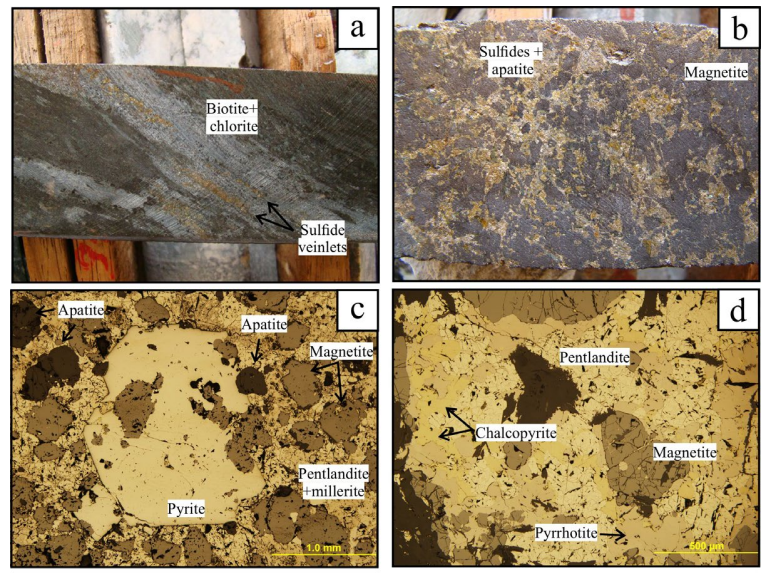

Figure 1 - Representative photos and photomicrographs of the Jaguar deposit. (a) Felsic subvolcanic rock extensively altered to biotite and chlorite, and disseminated sulfide veinlets. (b) Mineralized sulfide-magnetite-apatite-quartz breccia. (c) Coarse-grained euhedral to subhhedral pyrite and magnetite
surrounded by pentlandite and millerite, with disseminated apatite. (d) Massive sulfide ore comprising pyrrhotite, pentlandite and chalcopyrite with disseminated magnetite. This style of mineralization is rare at the deposit. The cores are $5 \mathrm{~cm}$ wide in photos (a) and (b).

Iron oxide copper-gold (IOCG) and Kiruna-type iron oxideapatite (IOA) deposits are closely associated with one another in several geological provinces [1]. The Carajás Mineral Province, Brazil, is known for the presence of several IOCG deposits [2], however, no IOA deposit was found in the province until present. The Jaguar nickel deposit represents an important and unconventional discovery of hydrothermal Ni resources $(58.9 \mathrm{Mt}$ (a) $0.95 \% \mathrm{Ni}$; [3]) associated with magnetite and apatite within the Carajás Mineral Province [4]. The Jaguar deposit shares several similarities with IOCG deposits found within the Carajás Mineral Province, especially regarding the structural control, and the hydrothermal alteration [4]. These similarities raise the possibility that the Jaguar deposit may represent a Ni-rich IOA member of the regional IOCG system found within the province. The deposit occurs near mafic-ultramafic intrusions, along a regional fault zone, and is hosted either by granitic (northern portion) or felsic subvolcanic (southern portion) rocks. The deposit is characterized by sub-vertical zones hosting a biotitechlorite hydrothermal alteration with ductile structures and disseminated sulfides (pyrite and millerite) and magnetite (Fig. 1a). These zones are overprinted by sulfide-magnetite-apatitequartz-bearing breccias, which represent the main mineralization bodies (Fig. 1b). The sulfide assemblage in the mineralized zones is dominated by pyrite, pentlandite and millerite (Fig. 1c), with minor sphalerite and chalcopyrite. Remarkably, they closely resemble magmatic sulfides (pyrrhotite, pentlandite and chalcopyrite; Fig. 1d), altered by fluids (pyrite and millerite) but the abundance of magnetite and apatite is unusual for magmatic sulfide deposits (Fig. 1b). We have investigated the concentration of trace elements in the magnetite and sulfides from the host rocks, different alteration facies and the mineralization found at Jaguar deposit by LA-ICP-MS. This will allow us to understand the sources of the hydrothermal fluids, a potential link with magmatic sulfide deposits nearby, and constrain whether the deposit may represent an IOA member within the IOCG system from the Carajás Mineral Province.

[1] Simon et al (2018) Econ Geol 21, 89-114.

[2] Moreto et al (2015) Mineral Deposita 50(5), 517-546.

[3] Centaurus Metals Ltd - Report, February 2021.

[4] Oliveira (2017) Unpub MSc thesis. Universidade de Brasilia, 115pp. 